\title{
Corrigendum
}

\section{Mental disorders among college students in the World Health Organization World Mental Health Surveys - CORRIGENDUM}

\author{
R. P. Auerbach, J. Alonso, W. G. Axinn, P. Cuijpers, D. D. Ebert, J. G. Green, I. Hwang, \\ R. C. Kessler, H. Liu, P. Mortier, M. K. Nock, S. Pinder-Amaker, N. A. Sampson, S. Aguilar-Gaxiola, \\ A. Al-Hamzawi, L. H. Andrade, C. Benjet, J. M. Caldas-de-Almeida, K. Demyttenaere, S. Florescu, \\ G. de Girolamo, O. Gureje, J. M. Haro, E. G. Karam, A. Kiejna, V. Kovess-Masfety, S. Lee, \\ J. J. McGrath, S. O’Neill, B.-E. Pennell, K. Scott, M. ten Have, Y. Torres, A. M. Zaslavsky, Z. Zarkov \\ and R. Bruffaerts
}

https://doi.org/10.1017/S0033291716001665, was first published online by Cambridge University Press 03 August 2016

Key words: College attrition, college dropout, education, epidemiology, mental illness.

In the above article (Auerbach et al. 2016) there was an omission in a funding source which should have been listed in the acknowledgements section of the article.

'Liu's work was supported in part by a training grant from the National Institute of Mental Health (T32 MH017119)'

This has now been included in the original version of the article.

\section{Reference}

Auerbach RP, Alonso J, Axinn WG, Cuijpers P, Ebert DD, Green JG, Hwang I, Kessler RC, Liu H, Mortier P, Nock MK, Pinder-Amaker S, Sampson NA, Aguilar-Gaxiola S, Al-Hamzawi A, Andrade LH, Benjet C, Caldas-de-Almeida JM, Demyttenaere K, Florescu S, de Girolamo G, Gureje O, Haro JM, Karam EG, Kiejna A, Kovess-Masfety V, Lee S, McGrath JJ, O’Neill S, Pennell B-E, Scott K, ten Have M, Torres Y, Zaslavsky AM, Zarkov Z, Bruffaerts R (2016). Mental disorders among college students in the World Health Organization World Mental Health Surveys. Psychological Medicine 46, 2955-2970. doi:10.1017/S0033291716001665. 